\title{
A generation gap between children and their parents in Pashtun community Buner District, Khyber Pakhtunkhwa, Pakistan
}

\section{Kesenjangan generasi antara anak-anak dan orang tua pada komunitas Pashtun di Distrik Buner, Khyber Pakhtunkhwa, Pakistan}

\author{
Pir Wahab ${ }^{1 *}$, Shamas Ud Din ${ }^{2}$, Kinan Pasha ${ }^{3}$, Mukhtar Ahmed $^{1}$, Mujahid Hussain ${ }^{4}$, \& \\ Jamil Khan ${ }^{5}$ \\ ${ }^{1}$ Department of Sociology, Faculty of Social Sciences, PMAS-Arid Agriculture University \\ ${ }^{2}$ Pakistan Institute of Medical Sciences \\ ${ }^{3}$ Department of Sociology, Faculty of Social Sciences, Abdul Wali Khan University Mardan \\ ${ }^{4}$ Department of Humanities and Social Sciences, Bahria University \\ ${ }^{5}$ Department of Sociology, Faculty of Social Sciences, University of Malakand \\ Address: ${ }^{1}$ Shamsabad, Muree Road, Punjab Rawalpindi, Pakistan 46000 \\ ${ }^{2}$ PIMS Hospital, Sector G-8/3 Islamabad, Pakistan \\ ${ }^{3}$ Nowshera Road, College Chowk, Muslimabad, Mardan, Khyber Pakhtunkhwa, Pakistan \\ ${ }^{4}$ Shangrilla Rd, E-8/1 E 8/1 E-8, Islamabad, Pakistan \\ ${ }^{5}$ Chakdara, Lower Dir, Khyber Pakhtunkhwa, Pakistan 18800 \\ E-mail: wahabanthro@gmail.com
}

Article History: Received 01 May 2021; Accepted 08 December 2021; Published Online 08 February 2022

\begin{abstract}
The generation gap is a serious, challengeable problem in the emerging society in Pakistan. It refers to parents or elders' disagreements, conflicts, inconsistencies, and differences in several matters such as attitude, behaviour, beliefs, values, politics, closeness, modern technology, cultural changes, and communication. The present study was designed to analyse the causes and consequences of the generation gap among the Pashtun community. A quantitative research method was used to select 400 samples of the current population and collect data through a well-designed questionnaire. The validity and reliability of the questionnaire were examined by ten PhD scholars from different universities. The Cronbach's Alpha for the data is .969. The data was analysed using SPSS version 26. The results were shown in the form of a one-way ANOVA and a frequency distribution table. The data revealed a statistically significant $(0.05)$ relationship between various variables such as technological advancement, living patterns, behaviour, social norms, communication gaps, unemployment, poverty, socioeconomic status, and religiosity. Both parents and children are responsible for the generation gap, but it can be reduced by understanding, loving, caring, sharing, communicating, and maintaining friendly relations.
\end{abstract}

Keywords: culture diversity; generation gap; religiosity; society; technology

\section{Abstrak}

Kesenjangan generasi menjadi masalah yang serius dan menantang pada perkembangan masyarakat di Pakistan. Kesenjangan generasi mengacu pada ketidaksepakatan, konflik, ketidakserasian, dan perbedaan orang tua atau lansia dalam beberapa hal seperti sikap, perilaku, keyakinan, nilai, politik, kedekatan, perkembangan teknologi, perubahan budaya, dan komunikasi. Penelitian ini dirancang untuk menganalisis penyebab dan konsekuensi dari kesenjangan generasi pada komunitas Pashtun. Metode penelitian kuantitatif digunakan untuk memilih 400 sampel dari populasi saat ini dan mengumpulkan data melalui kuesioner yang telah dirancang dengan baik. Validitas dan reliabilitas kuesioner dinilai oleh sepuluh mahasiswa S3 dari universitas berbeda. Alfa Cronbach yang digunakan untuk data tersebut adalah 0,969. Data dianalisis menggunakan SPSS versi 26. Hasil penelitian ditampilkan dalam bentuk ANOVA satu arah dan tabel distribusi frekuensi. Data tersebut menunjukkan hubungan yang signifikan secara statistik (0,05) antara berbagai variabel seperti kemajuan teknologi, pola hidup, perilaku, norma sosial, kesenjangan komunikasi, pengangguran, kemiskinan, status sosial ekonomi, dan religiositas. Orang tua maupun anak-anak sama-sama bertanggung jawab atas kesenjangan generasi, tetapi hal ini dapat dikurangi dengan saling memahami, mencintai, peduli, berbagi, berkomunikasi, dan memelihara hubungan dengan rukun.

Kata kunci: keragaman budaya; kesenjangan generasi; religiositas; masyarakat; teknologi 


\section{Introduction}

The age gap or generation gap is a divergence in opinion between one generation and another about views, customs, values, norms, technology advancement, and politics (Clark 2009). The disparity between generations was noted by Furlong (2016), who stressed that as youth transit into adulthood, this disparity between generations becomes more prominent. According to Furlong, some of these differences is natural, while others are deliberate and can be seen in places where people might gather such as the market, shopping malls, bars, coffee shops, and other activity centres. The generation gap exists because of the disparity between ages, races, genders, and societies that produce different beliefs and attitudes towards the same subject. Value shifts are focused on past years, which is the key explanation for the generation gap. According to Pabst (2012), there tend to be at least five distinct generation definitions widely used, including the stage of development, ordered descent, homogeneous age group, period, and age spirit.

The last definition varies from the very first four because, instead of relating to information, it relates to information. According to McCrindle (2006), the generation can be divided into five groups based on the year of birth, including the builders or also known as the Traditional and Silent Generation (Before 1946), Baby Boomers (1946-1964), Generation X (1965-1979), Millennial Generation Y (1980-1994), and Generation Z (1995-2009). The variation in beliefs, responses, and actions is likely to vary through generations. A generation gap is an age difference and a continuous process that varies in attitudes, beliefs, and habits. These differences may be modified during the life cycle or career stage of an employee and workers which may eventually be generic (Jurkiewicz \& Brown 1998).

In the 1960s, the sociological concept of a generation gap first came to light when the younger generation, now known as the Baby Boomers, demonstrated a significant gap in beliefs and opinions of their parents in daily life (Govitvatana 2001). Since then, several reports by Emery et al. (2015) have found that physical isolation generally integrates generational mental isolation, i.e., you will typically see no contact or even contact barriers through the ages. This isolation used to be obvious when there were age gaps of around a decade or more, but today we would find this physical isolation even when the age gap is less than three years. In reality, the challenges such as communication gaps, use of modern technology, and cultural and social barriers are getting so complex now that it is difficult to see how this chain might be broken.

The review of the literary analysis of the generation gap reveals that there are various forms of beliefs about the extent of the gap. Some studies show that the difference between the generations is too broad. Other findings show that there is no significant difference between today's generations. Moreover, what is encountered is just part of the standards of every other generation. Other evidence strongly suggests that generations have selective differences between them. Therefore, we can see that there are studies that are negative about the generation gap, as well as those that are favourable about it. According to some studies, generational differences are the cause of identity crises while religion, education, or culture are the cause of the fading position of traditional relationships (Collier \& Morgan 2008).

It is widely acknowledged that the generation gap in the use of information and communication technologies (ICTs) is correlated with problems around the world. Roman \& Colle (2002) indicated that generation gaps may present a possible obstacle in the use of ICTs for community growth since they indicated a situation in which a telecentre initiative had to have different places for young people and adults to engage in events, as the presence of each was completely overwhelmed by each community. Researchers have also found, however, that there are advantages to be gained from intergenerational experiences related to the use of technologies, such as the exchange of information and enhanced awareness of generational experiences (Wright 2000, Caskey 2002). A generation is described as "an identifiable group that at critical developmental stages shares birth years, age, and significant life events" (Parry \& Urwin 2017). 
In addition, intergenerational relations are characterized as "conversations of participants from various generations and interactions between them" (Sanchez 2006). Herring (2008) mentioned that 77 percent of young people use the internet. The younger generations continue to be more open to information and communication technology and thus, seem to have features similar to those of other generations from other parts of the world. In order to best explain the characteristics, character traits, and expectations of young people in these economies, a variety of studies have been performed to determine the gaps between generations (Herring 2008). Furthermore, the Pakistani younger generations faced numerous challenges directly related to their future, such as unemployment, poverty, political instability, cultural diversity, and technological advancement. Unfortunately, the lack of policy and negligence of the current government result in long periods of unemployment that lead to insecurity among younger generations (Adesina 2013).

Azeng \& Yogo (2013) studied the relationship between unemployment and political instability in developed countries. The results suggest that countries with high unemployment, socio-economic inequality, and level of corruption are vulnerable to national insecurity and political uncertainty. We are now living in a globalized world, a world that is witnessing unprecedented transformation as a result of enormous changes in emerging technologies, media, community, language, social media, and the fourth industrial revolution. All of these have led to the development of a fast and open means of contact between various individuals, communities, populations, cultures, and countries around the world. Recent advances in the fields of information technology, broadcast technology, and social broadcast have made the world a small global community, one in which people can interact with each other quickly and easily (Ali 2011). Individuals' overall digital connectivity is sometimes estimated to be $80-90$ percent, as revealed by the previous study. As a result of the remarkable and dramatic transition in new active technologies, media, and social media, positive and diverse elements have been added to human life in general. On the other hand, some young people face everyday inconsistencies in their lives owing to some of the nuances associated with technical advancements, leading to generational disparities and miscommunication that influence relationships. The age disparity between young people and their parents is the discrepancy between views, politics, or ideals. Another study also reveals the causes of the generation gap between children and their parents, which leads to an imbalance in society (Warschauer 2004).

This study aims to identify the causes and consequences of the generation gap between children and their parents in the Pashtun community. The current study was conducted in the Buner District. Buner District is situated in the Malakand Division in the Khyber Pakhtunkhwa Province of Pakistan. The native language is Pashto, which is spoken by $96.6 \%$ of the population. As per the census of population in 2017, the total population of Buner District was 897,319, which comprised approximately $48 \%$ male and $52 \%$ female. The entire region is homogeneous, but after partition in a fragmented manner, Hindu and Sikh minorities still live in the Buner District. Most of the population belongs to the Sunni school of thought (Hanafi) and traditionally wears Shalwar and Qamees. The Buner District area is largely surrounded by broad hills populated by pine trees. In the livelihood of the district, there are three major rivers, namely the Barandu, Chamla, and Budal. Much of the population belongs to agriculture, mining, and foreign remittances. Agriculture and livestock are the primary sources of their livelihood and the major crops are tobacco, maize, wheat, and sugarcane. The traditional family system still exists in this area, such as joint and extended families, and most of the structure of the house is made of clay and cement-like semi-pakha. Living conditions are steadily improving as most people work abroad as well as in major cities of Pakistan.

\section{Research Method}

The present research technique includes communication with respondents in order to better understand their opinions and perspectives regarding the generation gap. The study was conducted in the Gagra Tehsil (tehsil means an administrative subdivision of a district) of the Buner District of Khyber 
Pakhtunkhwa, Pakistan. The researcher used the Taro Yamane formula to calculate the sample size of the target population. Yamane (1967) provided an easy and simplest formula for sample size calculation. Multistage sampling techniques were applied to select 400 participants between different age groups, both males and females. The sample size of 400 participants is considered enough for the required target of the current study to investigate the generation gap between the younger generation and their parents.

A well-designed questionnaire was developed regarding important questions associated with the current issues of the generation gap and its day-to-day influence on the daily lives of both generations of children and their parents. The questionnaire was developed by considering the variations in thought and viewpoints of various generations. It was entirely neutral and as informative as possible so that we could get to the bottom of the issue. Male and female participants were chosen from various ages starting from 15 years. A well-designed questionnaire was used as an instrument for data collection. Two key informants were selected, one of whom was a social worker, and the age of both was 3035 years. The validity and reliability of the questionnaire were examined by ten $\mathrm{PhD}$ scholars from different universities, and the required reliability was calculated with Cronbach's Alpha. The Cronbach's Alpha reliability for the generation gap is .969 , which indicates the high reliability and validity of the questionnaire. The data was analysed using SPSS version 26 . The results were shown in the form of a one-way ANOVA and a frequency distribution table.

Selection and calculation of the sample size is the process of selecting the number of participants or replicates to be used in the representative study. The sample size of the study is an essential component of any scientific study in which the purpose is to make generalizations regarding the sample population (Hsieh et al. 1998). The researcher calculated the sample size by using the Taro Yamane formula with a $95 \%$ confidence level and $.05 \%$ margin of error. The total population of the current study is 270,467 individuals from the data of Gagra Tehsil of Buner District according to the population census of 2017. The Taro Yamane Formula was applied to obtain and calculate the sample size from the current population as shown below:

$$
\begin{aligned}
& \mathrm{n}=\mathrm{N} /[1+\mathrm{N}(\mathrm{e}) 2] \\
& \mathrm{n}=270,467 /[1+270,467(.05) 2] \\
& \mathrm{n}=270,467 / 270,468 \times 0.0025 \\
& \mathrm{n}=270,467 / 676.17 \\
& \mathrm{n}=400
\end{aligned}
$$

Where small " $\mathrm{n}$ " is the sample size, capital " $\mathrm{N}$ " is the population size, " $\mathrm{e}$ " is the margin of error or level of precision and " 1 " is the constant value.

Table 1.

Age category of the respondents

\begin{tabular}{lcc}
\hline Age category & Frequency & Percentage \\
\hline $15-30$ & 160 & $40.0 \%$ \\
$31-45$ & 119 & $29.8 \%$ \\
$46-60$ & 77 & $19.2 \%$ \\
61 and above & 44 & $11.0 \%$ \\
\hline Total & $\mathbf{4 0 0}$ & $\mathbf{1 0 0 . 0 \%}$ \\
\hline \multicolumn{3}{c}{ Source: Primary data }
\end{tabular}

Table 1 shows that the age category of the respondents was the younger generation between the ages of 15-30 years (40.0 percent), the age group of 31-45 years (29.8 percent), the age group of 46-60 years (19.2 percent), and 61 years or older (11.0 percent). According to the above data, the majority of the participants were aged between 15 and 45 years, which is classified as the young generation. One of the clearest indications of inter-generational attitudes characterized by age is the generation gap. 
According to Xenos \& Foot (2008), age is one of the core premises of social science because it is the views of others that influence our actions towards a generation. Age is a fundamental premise of lifecycle psychology and sociology, reflecting a significant factor in social interaction. In modern culture today, public policy and private concern about the generation gap are two related concepts. These concepts would indicate that people consider major variations in orientation between children and adults of different age groups. In addition, these disparities have behavioural implications for competition, disagreement, and income level. Views of ageing as a phenomenon certainly differ from perceptions of attitudes of age classes towards the elderly, middle-aged, and young people, or assessments of them.

\section{Results and Discussion}

The results and discussion section provide a brief interpretation of the current study regarding the generation gap between children and their parents. Results are displayed as a frequency distribution table and a one-way ANOVA analysis. Data analysis and results are displayed at the bottom of each table, along with table references and results.

Table 2.

Validity and reliability of the questionnaire

\begin{tabular}{clc}
\hline No. & \multicolumn{1}{c}{ Questions/dimension } & Cronbach's Alpha \\
\hline 1 & Technological advancement and information & .952 \\
2 & Personality characteristics and behaviour & .919 \\
3 & Living pattern and standard of life & .721 \\
4 & Traditional cultural values and social norms & .911 \\
5 & Communication gap with elders & .907 \\
6 & Level of information and religious practices & .870 \\
7 & Unemployment & .780 \\
8 & Poverty & .660 \\
9 & Socio-economic status & .952 \\
10 & Religion and level of understanding & .923 \\
\hline \multicolumn{2}{c}{ Total } & 10 \\
\hline \multicolumn{2}{c}{ Source: Primary data }
\end{tabular}

Table 2 shows the validity and reliability of the questionnaire. The reliability as indicated by Cronbach's Alpha of the above ten questions' is .969 within a 95\% confidence interval. Therefore, it shows that the questionnaire and data were excellent for analysis. Cronbach's Alpha is widely used for measures of reliability in the organizational and social sciences. Cronbach's Alpha reliability determines the measurements of the sum (average) reliability of questionnaires and test items. Cronbach's Alpha is a point in the measurements of internal consistency and reliability (Cronbach 1951).

Table 3.

Gender of the respondents

\begin{tabular}{lcc}
\hline Gender & Frequency & Percentage \\
\hline Male & 322 & $80.5 \%$ \\
Female & 78 & $19.5 \%$ \\
\hline Total & $\mathbf{4 0 0}$ & $\mathbf{1 0 0 . 0 \%}$ \\
\hline \multicolumn{3}{c}{ Source: Primary data }
\end{tabular}

Table 3 shows the distribution of the respondents regarding their gender. The majority of respondents (80.5 percent) were male and the rest (19.5 percent) were female. In terms of gender in the same population, the percentage of male participants is larger than that of female participants. Pashtun society, particularly in remote rural areas, is male-dominated. Female literacy is low as a result of cultural values, traditional values, and religious affiliation; all of which influence the dominance of a male-oriented 
society in this area. Cultural and religious orders are strictly followed by any member of society. Young women are strongly bound to work at home as this is considered a cultural taboo. Still, in this modern era, older people do not accept advancement and modernization around the world.

Human rights violations are committed against females in the name of traditional cultural value systems. The majority of the elderly do not involve younger generations, particularly females, in the processes of decision-making, property distribution, ownership, and education. Similarly, a study in Nigeria found that protections of civil and international laws examine the role of religion and cultural influence on female rights. On the one hand, religion gives women the right to buy and inherit property, but the traditional social system in Nigeria and Africa discriminates against them (Abara 2012). Being a Muslim provides a variety of protections for human rights as stated in the Holy Quran. In Pakistan, especially in Khyber Pakhtunkhwa, the dominance of culture and the use of wrong religious beliefs dictate social values, norms, customs, and behaviour towards women's rights. Culture has a drastic effect on female and younger generations' rights in Pakistan.

Table 4.

Marital status of the respondents

\begin{tabular}{lcc}
\hline Marital status & Frequency & Percentage \\
\hline Single & 85 & $21.2 \%$ \\
Married & 315 & $78.8 \%$ \\
\hline Total & $\mathbf{4 0 0}$ & $\mathbf{1 0 0 . 0 \%}$ \\
\hline \multicolumn{3}{c}{ Source: Primary data }
\end{tabular}

Table 4 reveals that the majority of the respondents ( 78.8 percent) were married, while the rest $(21.2$ percent) were single. Marriage is a social institution or social bond that admits both males and females to family life. It is a committed relationship in which a husband and wife are socially allowed to have children with the right to have sexual intercourse. Marriages are typically done in households with the permission of the parents. The family is considered to be a more essential institution than the individual. Children cannot consider themselves to be a person apart from, or even within, the family. Moreover, the patriarchal nature of the family leaves no space for individual actions and choices, not to mention intervention, except in important matters to individual personal life, especially marriage.

Table 5.

Family status of the respondents

\begin{tabular}{lcc}
\hline Family type & Frequency & Percentage \\
\hline Nuclear family & 110 & $27.5 \%$ \\
Joint family & 290 & $72.5 \%$ \\
\hline Total & $\mathbf{4 0 0}$ & $\mathbf{1 0 0 . 0 \%}$ \\
\hline \multicolumn{3}{c}{ Source: Primary data }
\end{tabular}

Table 5 represents the sample distribution of the respondents regarding their family status. The majority of the respondents ( 72.5 percent) lived in the joint family system, and the rest (27.5 percent) lived in the nuclear family system. According to the above findings, the majority of people preferred to live in a joint family system. Most of the people did not have enough opportunities for their standard life to live in the area. Therefore, approximately one person in the household earns abroad for their livelihood. The necessity of every joint family system is not fulfilled by one member of the household in the current situation. Financial responsibility and equal education, or any other decision, are very strict for younger generations. The head of the joint family system takes all the decisions and does not involve the family members. The attitude and behaviour of the older generation do not accept the younger generation, resulting in a generation gap between children and their older relatives. 
Buheji's (2019) argument supported the findings of this study that the household is the primary setting for learning and is influenced by the attitudes of children as they grow. The family is recognized as a major human interaction organization. For the diffusion of cultural norms to the next generation, the family is a significant institution for socialization. However, the framework for supervising the children in terms of cultural values and activities may be contradictory to the opinions of youth, which may lead to gaps and conflicts between generations. In the nuclear family, parents usually place fewer restrictions. The family atmosphere is more progressive. In a joint family, children not only need to respect their parents, but also other family members. Numerous regulations, rules, codes of ethics, etc. are imposed on them. As a consequence of such constraints, the growth of individual behaviour of the child is constrained, as this is the period where the child seeks to be emancipated from the restrictions enforced by the family. When seeking to accomplish this goal, they face family issues that influence family relationships.

\section{Test hypothesis}

$\mathrm{H}_{\mathrm{o}}$ : There are no differences between the age group of the respondents and dimensions of the generation gap

$\mathrm{H}_{\mathrm{a}}$ : There are differences between the age group of the respondents and dimensions of the generation gap

Table 6.

Applied one-way ANOVA analysis to check differences between means

\begin{tabular}{|c|c|c|c|c|c|c|}
\hline Dimensions of generation gap & Age group & ss & DF & MS & $\mathbf{F}$ & Sig. \\
\hline \multirow{3}{*}{$\begin{array}{l}\text { Technological advancement and } \\
\text { information }\end{array}$} & $\begin{array}{l}\text { Between } \\
\text { groups }\end{array}$ & 12.250 & 3 & 4.083 & 24.989 & .000 \\
\hline & Within groups & 64.710 & 396 & .163 & & \\
\hline & Total & 76.960 & 399 & & & \\
\hline \multirow{3}{*}{$\begin{array}{l}\text { Personality characteristics and } \\
\text { behaviour }\end{array}$} & $\begin{array}{l}\text { Between } \\
\text { groups }\end{array}$ & 27.227 & 3 & 9.076 & 64.697 & .000 \\
\hline & Within groups & 55.551 & 396 & .140 & & \\
\hline & Total & 82.778 & 399 & & & \\
\hline \multirow{3}{*}{$\begin{array}{l}\text { Living pattern and standard of } \\
\text { life }\end{array}$} & $\begin{array}{l}\text { Between } \\
\text { grouns }\end{array}$ & 54.865 & 3 & 18.288 & 174.408 & .000 \\
\hline & Within groups & 41.525 & 396 & .105 & & \\
\hline & Total & 96.390 & 399 & & & \\
\hline \multirow{3}{*}{$\begin{array}{l}\text { Traditional cultural values and } \\
\text { social norms }\end{array}$} & Between & 2.660 & 3 & .887 & 5.462 & .001 \\
\hline & Within groups & 64.278 & 396 & .162 & & \\
\hline & Total & 66.938 & 399 & & & \\
\hline \multirow{3}{*}{$\begin{array}{l}\text { Communication gap with their } \\
\text { elders }\end{array}$} & $\begin{array}{l}\text { Between } \\
\text { groups }\end{array}$ & 7.351 & 3 & 2.450 & 13.844 & .000 \\
\hline & Within groups & 70.087 & 396 & .177 & & \\
\hline & Total & 77.438 & 399 & & & \\
\hline \multirow{3}{*}{$\begin{array}{l}\text { Level of information and } \\
\text { religious practices }\end{array}$} & $\begin{array}{l}\text { Between } \\
\text { groups }\end{array}$ & 3.074 & 3 & 1.025 & 7.012 & .000 \\
\hline & Within groups & 57.864 & 396 & .146 & & \\
\hline & Total & 60.937 & 399 & & & \\
\hline \multirow{3}{*}{ Unemployment } & $\begin{array}{l}\text { Between } \\
\text { groups }\end{array}$ & 5.634 & 3 & 1.878 & 16.650 & .000 \\
\hline & Within groups & 44.664 & 396 & .113 & & \\
\hline & Total & 50.298 & 399 & & & \\
\hline
\end{tabular}




\begin{tabular}{|c|c|c|c|c|c|c|}
\hline \multirow{2}{*}{ Poverty } & Between & 6.968 & 3 & 2.323 & 29.283 & .000 \\
\hline & Within groups & 31.410 & 396 & .079 & & \\
\hline & Total & 38.378 & 399 & & & \\
\hline \multirow{3}{*}{ Socio-economic status } & $\begin{array}{l}\text { Between } \\
\text { groups }\end{array}$ & 12.250 & 3 & 4.083 & 24.989 & .000 \\
\hline & Within groups & 64.710 & 396 & .163 & & \\
\hline & Total & 76.960 & 399 & & & \\
\hline \multirow{3}{*}{$\begin{array}{l}\text { Religion and level of } \\
\text { understanding }\end{array}$} & $\begin{array}{l}\text { Between } \\
\text { groups }\end{array}$ & 25.832 & 3 & 8.611 & 60.321 & .000 \\
\hline & Within groups & 56.528 & 396 & .143 & & \\
\hline & Total & 82.360 & 399 & & & \\
\hline
\end{tabular}

Statistically significant at $(0.05 \geq \alpha)$

Source: Primary data

Table 6 represents that one-way ANOVA was used to know the difference mean between the generation gap of children and their parents with the help of a questionnaire and related questions. The results of the above table demonstrated that all dimensions of the generation gap as shown by the F-value is statistically significant at $(\alpha \leq 0.05)$ level. However, the results indicate that there are no differences between the age factor and dimensions of the generation gap. Therefore, we accepted the null hypothesis and rejected the alternative hypothesis. There are statistically significant differences between age groups at the level of $(\alpha \leq 0.05)$ for all dimensions of the generation gap or related questions. Therefore, we conclude that all factors shown in the table, such as technological advancement and information, personality characteristics and behaviour, living pattern and standard of life, traditional cultural values and social norms, communication gaps with their elders, level of information and religious practices, unemployment, poverty, and socio-economic status are interconnected between two generations.

\section{Revolution of technology}

The above detailed results provide a qualitative explanation, and the researcher also observed that technological advancement and a lack of information about technology are the main causes of the generation gap. The younger generation uses technology to pass the time and does not pay attention to their parents and family connections. However, if the younger generation uses modern technology for their learning process in terms of education and online earning, then their parents are compromised. On the other hand, there is the fact that the parents or older generations do not know about the use of modern technology for positive purposes. Most elderly people waste their time on social media by just watching videos and searching various sites for their satisfaction. Behaviour and personality characteristics depend on the use of technology. University students have larger generation gaps with their parents and elders than school-age and illiterate students. In terms of connectivity and communication, there is a huge gap between the younger generation and their families. Existing research agrees that the younger generation makes more use of mobile phones, social media, and other electronic devices to communicate as compared to their elders (Baker et al. 2012).

In the current research study, the researcher's opinion is that the fast-paced development of technology and society promotes generation gaps. In earlier times, the development process was very slow. Therefore, two or three generations lived in the same environment and lifestyle. Due to modern technologies, the world is more advanced today than ever before, and the process of development is very fast. However, the older generations and parents do not know the need and use of modern technologies as compared to the new generations. Effectively, recent technological advancements have boosted actual growth in every field, and anything that was previously thought to be impossible is now regarded normal in a relatively short time. Our parents lived in and adapted to a much slower world. Now even though the intensity has changed considerably, they still have the same habits as before. The components that were perceived as luxuries to a certain degree are today's necessities. 
It is very difficult for individuals who are already accustomed to a certain lifestyle to adapt to new patterns and requirements. The younger generations are progressively understanding and adopting the new challenges of a rapidly growing world, which is sometimes a problem for their parents. The work style, habits, passion for work, and any other living pattern are quite different. According to the above, fact, the researcher agrees that it is impossible for parents to adopt the emerging society and advancement of technology, and it is also difficult for the younger generation to help them understand. Previous results provide a concrete argument that most people have a very busy and tough life. They do not have any extra time for rest, which is sometimes exacerbated by the usage of mobile phones and other forms of technology. On the other hand, our elderly people are much slower decision-makers. Parents are more in a controlling capacity and should seek to get connected with the latest developments. If they do not seek or adopt the new emerging changes, they should at least try and consider their children's needs and remove the barriers. The generation gap can be overcome by parents by developing close friendships with children and providing opportunities while getting out of the respect perspective (Fogelholm et al. 1999).

\section{Marital life and traditional value system}

This study observed in the field study that the Pashtun society strongly believed in cultural and religious practices and that they were also interconnected. In the context of the traditional value system, the head of the household in the joint family system is predominant. The style of the decision-making process also causes dissatisfaction and stresses the connection between children and parents. In several families, parents make arrangements for their children, especially girls, to marry. However, the situation is changing; the modern younger generations are not ready at an early age to take on family responsibilities. They want to settle down by choosing a proper job first in their life and then, imagining their married life. Today, the biggest reason parents and children step away from each other is the generational or age gap. As we all know, the world has changed through technological advancement. Therefore, the standard of life, living patterns, and minds of children have changed as well.

The new generations do not like or accept the orders and decisions of their parents or elders being enforced on them. The current results show a fact that the new generation does not like interfering in any of the personal matters in their lives, especially marriage proposals. Our society's refusal to accept the opinions, views, and decisions of youngsters by their elders has resulted in the generation gap. The children are depressed and do not share their points of view with their elders in the name of honour. Parents or grandparents do not have time for their children because they are too busy with their work and careers. If the parents devote some time to their children and make a friendship bond with them, then there will be no issues or problems. Often parents need to behave as a friend to children to better understand them. The generation gap is nothing but a social, psychological, and emotional disparity between the younger generation and the elderly. Marital satisfaction is a growing concern in modern society.

Previous studies integrated Salazar \& Nguyen's (2019) theory of marital satisfaction into marital satisfaction from a life span developmental perspective. Couples have multiple goals to achieve in their marriage, such as personal growth, companionship, and instrumental goals. The priority of the three types of marital goals is subject to dynamic changes across adulthood. Generally speaking, young couples emphasize their personal growth goals; middle-aged couples prioritize their instrumental goals; and elderly couples focus on their companionship goals. The achievement of the marriage goals that are prioritized in marriage determines marital satisfaction. Some factors influencing marital satisfaction can be linked with marital goals in two ways. Factors such as life transitions and cultural values can affect the priority of different marital goals, while others, such as communication patterns, problem-solving, and attribution, can facilitate the achievement of the prioritized marital goals. 


\section{Religiosity and marital satisfaction}

This study analyzed and observed in the light of literature that many cultures around the world, religions, and human life have a closer connection. The sociology of religion focuses on the socio-cultural and married lives of men and women. Couples who adhere to religions are more likely to have a stronger marital commitment, which enhances their marital relationship. Several authors have emphasized the invaluable role of religious practices and their effects on marital satisfaction. Religiosity plays an important role in improving marital satisfaction. However, there is a lack of research and knowledge to understand the effect of religiosity on marital satisfaction in the Pakistani context (Hood et al. 2018). Table 5 above showed the result of the current study that the level of religious understanding was very poor and most people apply their thoughts, which is harmful to the levies of a marital couple.

Religion has played a major role in increasing marriage happiness and has influenced the consequences of human life challenges. The association between religiosity level and marital happiness is positively linked; highly religious married couples have a healthier, more secure marriage life relative to other couples. Islamic teachings on marital happiness and family relationships are discussed from the respondents' point of view. They also expressed and described vital issues including women's fundamental rights, gender roles, and the harmony of family relations. Marital engagement and pleasure are significant for enhancing the level of satisfaction of the spouses in assessing various aspects of their marital relationship. Commonly, the value of husband-and-wife engagement reflects the feeling of satisfaction and fulfilment of persons in their marital relationship. The hierarchy of gender and family relationships between spouses is seen as the main family relationships. This is also in accordance with the shariah; husbands are in charge of the responsibilities and commitments of the family (Zaloudek 2014).

\section{Family life and socialization}

Being a Pashtun, the researcher observed and knew the norms and values of the Pashtun community that family is considered as a major important network of socialization. Family is the fundamental setting where the children become socialized and gain the first experience and are influenced by the transforming attitudes and the behaviour of the parents. The family is also a significant transmitting channel for the transmission of cultural norms, values, traditions, and religious practices to the next generation. However, the framework for the regulation of the child in terms of societal objectives and behaviour runs contrary to the opinions of youth, which may contribute to generational disparities and potential conflict. In the nuclear family system, parents or elders are usually democratic and impose fewer restrictions on their young generations.

In the joint family system, the children have to follow not only their elders' or parents' decisions or orders but also obey other members of the family. Every community has its code of conduct, rules, and regulation that are imposed on the next generations. As a result and consequences of such enforced, restricted rules, children search for emancipation, freedom from the imposed restrictions by the elders or parents in the same family. Moreover, teenagers need to gain more freedom of choice, physiological flexibility, emotional freedom, and meaning of independence. However, the adolescents face issues to achieve these flexibilities in the term of the joint family system, which destroys and damages the family relationship (Thornberg \& Knutsen 2011).

\section{Poor communication}

In fact, the researcher deeply studies and understand that the generation gap among children and parents leads to poor interaction or poor communication. It should be remembered that the age difference for all families does not necessarily occur. Very commonly, parents and children have different thoughts and opinions, which is not really a conflict in itself. Parents must understand that children need to have some space to understand everything. They should keep an eye on children, but not impose any restrictions on 
them. As per the report, it was concluded that one of the key explanations for the generation gap is lack of communication. Parents are extremely pressured to maintain a work-family balance. Even though they do so to give their children a good life, they forget that it costs them time with their children. They expend much of their time on heavy workloads and job pressures. Children, on the other hand, do not share their academic performance and daily lives with their parents. In general, parents make tremendous sacrifices to make a living, while at the same time the children are ignored, creating communication barriers in the family and leading to the generation gap.

According to Laursen \& Collins (2004), the digital advancement we are now living in a globalized world produce a society that is evolving increasingly as a result of enormous developments in emerging technologies, media, culture, language, social media, and the fourth industrial revolution. All of these have helped to establish a swift and open means of communication across the world between different individuals, households, communities, cultures, and nations. In the field of emerging technologies, information sharing technology and social media, the significant advancements we have seen have made the globe a virtual global community in which people can interact with each other quickly and easily. Parents may need to help their children and respectfully encourage them with the right figures and facts to lead them in the right direction. And in this manner, the age gap will be slowly resolved. It is a heavy burden on the shoulders of parents to support children appropriately. They should accomplish this in the best possible way. Their time should not be diverted to needless events. Parents need to concentrate on good relationships with their children rather than relying on a successful career. The changes in our social expectations bring about a major change in family relations. This is how society invents the system and infuses it with elements of its thoughts, values, power, principles, and perversions. Society is made up of collaborations. The more people infuse teamwork, affection, commitment, and integrity in relationships, the more society will flourish.

\section{Conclusion}

The current study was conducted to find and understand the reasons behind the generation gap between children and their parents in the Pashtun community in Buner District, Khyber Pakhtunkhwa, Pakistan. The sample of 400 participants, both male and female, aged up to 15 years, revealed that there is a high generation gap between the younger generation and their parents. The factors behind the generation gap are modern technology, behaviour, personality characteristics, lifestyle, traditional value systems, social norms, unemployment, poverty, poor communication skills, and religiosity. Due to traditional value systems and social norms, there was a high generation gap between parents and their children. There is a huge gap in the way of poor communication and friendly relations between parents and children in the name of honour and cultural values. Moreover, the use of modern technology in emerging societies plays a significant role in promoting a generation gap. Due to rapid change around the world, modernization becomes the main cause of the generation gap. The old people do not know the use of modern technology. Their beliefs and value systems are very strong and they do not easily adapt or accept changes in the modern era.

The results revealed that the impact of religiosity, wrong interpretation of religious beliefs, and lack of knowledge become a huge difference in children and parents. A joint family system exists in the Pashtun community, which also influences the marital lives of individuals. Any member of the joint family system is denied equal opportunity. Approximately, most of the older people do not involve their children, especially females, in decision-making in joint family systems. All decisions are made by the head of the household, and they do not negotiate in terms of marriage, which is a basic human right for anyone. However, the information or knowledge of the generation gap is essential for an effective counselling programme for both children and parents. It is also beneficial for key policymakers to organize various seminars and programmes for the counselling of older generations in order to play a role in bridging the generation gap. 


\section{References}

Abara CJ (2012) Inequality and discrimination in Nigeria tradition and religion as negative factors affecting gender. Federation of International Human Rights Museums, 1-18.

Ali AH (2011) The power of social media in developing nations: New tools for closing the global digital divide and beyond. Harvard Human Rights Journal 24:185-219.

Azeng TF \& Yogo TU (2013) Youth Unemployment and Political Instability in Selected Developing Countries. Tunisia: African Development Bank Tunis.

Adesina OS (2013) Unemployment and security challenges in Nigeria. International Journal of Humanities and Social Science 3 (7):146-56.

Baker WM, Lusk EJ, \& Neuhauser KL (2012) On the use of cell phones and other electronic devices in the classroom: Evidence from a survey of faculty and students. Journal of Education for Business 87 (5):275-289. http://dx.doi.org/10.1080/08832323.2011.622814.

Buheji M (2019) Alleviation of generation gap through socio-economic issues involvement. European studies review 11 (4):12-20. http://dx.doi.org/10.5539/res.v11n4p12.

Caskey MM (2002) Using parent-student pairs for internet instruction. Journal of Research on Technology in Education 34 (3):304-317. http://dx.doi.org/10.1080/15391523.2002.10782351.

Clark LS (2009) Digital media and the generation gap: Qualitative research on us teens and their parents. Information, Communication \& Society 12 (3):388-407. https://doi. org/10.1080/13691180902823845.

Collier PJ \& Morgan DL (2008) Is that paper really due today? Differences in first-generation and traditional college students' understandings of faculty expectations. Higher education 55 (4):425446. https://doi.org/10.1007/s10734-007-9065-5.

Cronbach LJ (1951) Coefficient alpha and the internal structure of tests. Psychometrika 16 (3):297-334. https://doi.org/10.1007/BF02310555.

Emery SJ, Pascovi D, Lacey E, \& Haynes PA (2015) The generation gap: Proteome changes and strain variation during encystation in Giardia duodenalis. Molecular and Biochemical Parasitology 201 (1):47-56. https://doi.org/10.1016/j.molbiopara.2015.05.007.

Fogelholm M, Nuutinen O, Pasanen M, Myohanen E, \& Saatela T (1999) Parent-child relationship of physical activity patterns and obesity. International Journal of Obesity Related Metabolic Disorders 23 (12):1262-1268. https://doi.org/10.1038/sj.ijo.0801061.

Furlong A (2016) The Changing Landscape of Youth and Young Adulthood. Routledge Handbook of Youth and Young Adulthood.

Govitvatana WV (2001) Generation gap in the workplace between baby boomers and generation X. Thesis, University of Wisconsin-Stout, Menomonie.

Herring SC (2008) Questioning the Generational Divide: Technological Exoticism and Adult Constructions of Online Youth Identity. (In press). In D. Buckingham (ed.). Identity. MacArthur Series on Digital Media and Learning. Cambridge, MA: The MIT Press. 71-92.

Hood RW, Hill PC, \& Spilka B (2018) The Psychology of Religion: An Empirical Approach. Guilford Publications.

Hsieh FY, Bloch DA, \& Larsen MD (1998) A simple method of sample size calculation for linear and logistic regression. Statistics in Medicine 17 (14):1623-1634.

Jurkiewicz CL \& Brown RG (1998) Generational comparisons of public employee motivation. Review of Public Personnel Administration 18 (4):18-37. https://doi.org/10.1177/0734371X9801800403.

Laursen B \& Collins WA (2004) Parent-Child Communication During Adolescence. The Routledge Handbook of Family Communication.

McCrindle M (2006) New Generations at Work: Attracting, Recruiting, Retaining and Training Generation Y. McCrindle Reseacrh.

Pabst O (2012) New concepts in the generation and functions of iga. Nature Reviews Immunology 12 (12):821-832. https://doi.org/10.1038/nri3322.

Parry E \& Urwin P (2017) The evidence base for generational differences: Where do we go from here? Work, Aging and Retirement 3 (2):140-148. https://doi.org/10.1093/workar/waw037. 
Roman R \& Colle RD (2002) Creating a participatory telecenter enterprise. Paper presented at the Participatory Communication Research Section, 21-26 July, Barcelona. Spain: International Association for Media and Communication Research.

Salazar LR \& Nguyen T (2019) An examination of work-life balance, listening satisfaction, and relationship dissolution among marital and cohabiting couples. Primenjena Psihologija 12 (4):429-452. https://doi.org/10.19090/pp.2019.4.429-452.

Sanchez M (2006) Challenges to intergenerational studies: Perspective from western Europe. Journal of Intergenerational Relationships 4 (2):107-110. https://doi.org/10.1300/J194v04n02_09.

Thornberg R \& Knutsen S (2011) Teenagers' explanations of bullying. Child \& Youth Care Forum 40 (3):177-192. https://doi.org/10.1007/s10566-010-9129-z.

Warschauer M (2004) Technology and Social Inclusion: Rethinking the Digital Divide. Cambridge: MIT Press.

Wright K (2000) Computer-mediated social support, older adults, and coping. Journal of Communication 50 (3):100-118. https://doi.org/10.1111/j.1460-2466.2000.tb02855.x.

Xenos M \& Foot K (2008) Not your father's internet: The generation gap in online politics. Civic Life Online: Learning How Digital Media Can Engage Youth. Edited by W. Lance Bennett. The John D. and Catherine T. MacArthur Foundation Series on Digital Media and Learning. Cambridge, MA: The MIT Press. 51-70. https://doi.org/10.1162/dmal.9780262524827.051.

Yamane T (1967) Statistics: An introductory analysis. New York: Harper and Row.

Zaloudek JA (2014) Evangelicals' sanctification of marriage through the metaphor of Jesus as a husband. Religions 5 (3):623-647. https://doi.org/10.3390/rel5030623. 